\title{
Medyadaki Etik Sorunlardan Biri Olarak Cinsiyet Ayrımcılığı: Magazin Basınından Örnek Haber İncelemesi
}

\author{
DOI: $10.26466 /$ opus.524006 \\ * \\ Özgehan Özkan ${ }^{*}$
}

\begin{abstract}
* Dr. Öğr. Üyesi, Trabzon Üniversitesi, İletişim Fakültesi, Söğütlü/Trabzon/Türkiye E-Posta: ozgehan8@yahoo.com.tr

ORCID: 0000-0002-2556-0237
\end{abstract}

\section{Öz}

\begin{abstract}
"Medya toplumu mu yansıtır, yoksa medyanın konuları sunuş biçimi mi kamuoyunu şekillendirir" sorusu iletişim araştırmalarının başlıca konusudur. Bu konudaki kuramsal yaklaşımlar, medyanın kamuoyu oluşturmadaki etkisini kabul etmektedir. Medya, habere konu teşkil eden konuları işleyiş biçimi ile bir algı inşası gerçekleştirmektedir. Bu tespit, ikili ilişkilerdeki aldatma konusu için de geçerlidir. Magazin basınının konusu olan tanınmış kişilerin ikili ilişkilerindeki aldatma haberlerinde konunun temsili ağırlıkl olarak kadın merkezli olarak verilmekte, söz konusu davranışta en az kadın kadar payı olan erkeğin ismi neredeyse hiç geçmemektedir. Konunun erkek tarafi iradesi, inisiyatifi olmayan, kurallarım kadının koyduğu bir davranış modeli içinde pasif, masum bir "figüran" olarak konumlandırılmaktadır. Medyanın konuyu bu şekilde temsil etmesi, okur/izler kitlenin ikili ilişkilerde kadını yargılaması ve erkeği pasif, adeta görünmez kabul etmesi ile sonuçlanmaktadır. Başka bir ifade ile medya en temel ilkelerinden biri olan "Kamuoyunu tarafsız ve doğru bilgilendirme" görevini ihlal etmektedir. Medya, etik/ahlaki olmayan ve toplum tarafindan onaylanmayacak bir davranış biçimin olan "Aldatma" ile ilgili olarak haber dili üzerinden ă̆ırlıklı olarak kadını suçlamakta, kadının davranışlarını tartışmaya açmakta ve kamuoyu nezdinde kadının yargılanmasına zihinsel ortam hazırlamaktadır. Bu araştırmada magazin medyasının gündemine giren 3 örnek olay, çerçeveleme analizi ile desteklenen içerik analizi yöntemi ile ele alınacak ve medyanın konuyu temsil ediş biçimindeki yanlılık değerlendirilmeye çalışılacaktır.
\end{abstract}

Anahtar Kelimeler: Magazin, Medya, Cinsiyet ayrımcılı̆̆ı, Aldatma, Medya temsilleri, Etik 


\title{
One of The Ethic Problems in The Media: Gender Discrimination Sample News Analysis from Tabloid Media
}

\begin{abstract}
The question whether "the media reflect the society, or the way how the media presents subjects shapes the public" is the main issue of communication researches. The theoretical approaches in this field accept the influence of the media on creating a public opinion. The media carries out a perception construction with the way it processes the subject matter. This also applies to the issue of deception in bilateral relationships. In the cheating news in the bilateral relationships of the well-known persons who are the subject of the magazine press, the subject is mainly presented as women-centered and the name of the man who has at least as much share as the woman in the said behavior is almost never mentioned. The male side of the subject is positioned as a passive, innocent "figure" in a behavior model where the man does not have any initiative and whose rules the woman determines. The media's representation of the subject in this way results in the audience's / reader's judging of the woman in bilateral relationships and acceptance of the man as passive, quasi invisible. In other words, the media violates one of its most fundamental principles, "informing the public impartially and accurately". In relation to "Cheating", which is not a moral/ethical behavior and is a course of action that cannot be accepted by the society, the media mainly accuses the woman through the reporting style used in the news, opens the women's behavior to debate and publicly prepares a mental environment for the judgement of women. In this study, 3 sample cases which are on the agenda of the magazine media will be handled with the content analysis method supported by framing analysis and an evaluation on the media's partiality in the form of representation will be made.
\end{abstract}

Keywords: Tabloid, Media, Gender discrimination, Cheating, Media's representations, Ethics 


\section{Giriş}

Toplumun genelini ilgilendiren konularda bilgi edinilebilecek başlıca kaynak basındır. Siyaset, ekonomi, sağlik, eğitim, kültür sanat, bilim-teknik, spor, çevre, eğitim gibi alanlarda yaşanan her türlü gelişme medya arac1lığı ile öğrenilmektedir. Kamuoyu oluşmasının temelinde bu vardır. Kamuoyunun sağlıklı bir şekilde oluşabilmesi için medyanın konuları sunuş biçimi birinci derecede önem arz etmektedir. Haber bir metindir. Somut gerçekliğin haber dili şablonuna uygun olacak şekilde yeniden inşa edilmiş halidir. Haber metninden beklenen gerçekliği "Bir ayna gibi" okur/izler kitleye yansıtmasıdır. İfadeye yorum katmamasıdır. Tarafsız olmasidır. Dengeli olmasıdır, yani habere konu olan olayın bütün taraflarına eşit şekilde yer vermesidir. Bu durumda sorulması gereken sorular şunlardır: Basın bu ilkelere uygun içerik üretmekte midir? Kamuoyunun oluşmasında üzerine düşen tarafsız ve dengeli haber dilini sağlamakta mıdır? Yoksa gerçekliğin bir kısmını ön plana çıkarıp bir kısmını görmemekte midir?

$\mathrm{Bu}$ araştırmanın temel problemi bir örnek haber üzerinden basının nasıl bir sunum yaptığını ortaya koymaktır. İletişim, insanın kendi kendine olan iletişiminden; kitle iletişimine uzanan çok geniş bir yelpazedir. $\mathrm{Bu}$ yelpazenin bir bölümü de ikili ilişkiler-evlilik iletişimidir. Her iletişim biçiminde olduğu gibi burada da süreci bozan unsurlar olmaktadır. Evlilik söz konusu olduğunda bu iletişimi bozan başlıca unsur, evlilik akdi sona ermeden eşlerden birinin başkası ile ilişkiye başlamasıdır. Bu durum, üç taraflı bir iletişim bozukluğudur ve yeni ilişkiye başlayan iki taraf, ancak özellikle henüz evlilik akdi süren taraf toplumsal değerler nezdinde suçlu kabul edilmektedir. Aldatma sonucu evliliği zedelenen çift politikacı, sanatçı vb toplumun tanıdığı kişilerden oluşuyorsa konunun haber değeri vardır ve yukarıda sayılan ilkelere sadık kalmak şartıyla haber metni haline getirilerek okur/izler kitleye yansitılır. Olması gereken budur. Ancak bir de "olan" vardır ve bu araştırmanın problemi de olan durumu araştırmaktır. Basın "Aldatma" konusunu tarafsız, dengeli, yorum katmadan sunmakta mıdır? Yoksa kadın veya erkek lehine bir duruş mu sergilemektedir? Suçun tamamını tek bir tarafa yükleyerek değer tarafı görmezden gelmekte, adeta koruma altına mı almaktadır? Bu soruların yanıtlanabilmesi için çerçeveleme analizi ve söylem analizinden yararlanılmıştır. 


\section{Yöntem}

Araştırmada çerçeveleme yaklaşımı ve söylem analizi bir arada kullanılmıştır. Çerçeveleme yaklaşımı, haberin başlık, üst başlık, alt başlık, spot, görsel gibi okurun ilk olarak algıladığı temel unsurlarını ne şekilde oluşturduğunu, tarafsızlık ölçütüne ne derece bağlı kaldığını ortaya koymayı amaçlayan bir yaklaşımdır. "Çerçeveleme teorisi iletişim biliminin bütün alanlarında kullanılan teorik ve ampirik bir paradigma haline gelmiştir" (Özarslan ve Güran, 2015, s.32). Çerçeveleme yaklaşımına son dönem iletişim araştırmalarında sıklıkla başvurulmaktadır. Özellikle yazılı medyada habere konu olan gerçekliğin okura aktarılışı sırasında meydana gelen anlam kayıpları, kasıtlı veya kasıtsız anlam değişimleri tarafsızlığın sorgulanmasına neden olmaktadır ve bu tarafsızlığı saptamada çerçeveleme yaklaşımı araştırmacıya güvenilir veriler sağlamaktadır. Dursun'a (2004, s.40) göre haberin toplumsal gerçekliği yansıttığı önermesi tartışmaya açılmış ve bu görüş ciddi şekilde eleştirilmeye başlanmıştır. Gerçeklik medya üzerinden yeniden kurgulanmaktadır. Bu durum kamuoyunun sağlıklı oluşmasının önünde ciddi bir problem teşkil etmektedir. Medya okuryazarlığı eğitiminden geçmemiş okur/izler kitle için neyin gerçek, neyin kurgu olduğunu saptamak çok mümkün değildir. Üstelik dilin yapısal özellikleri nedeniyle taraflı bir metin okur tarafından tarafsız bir metin olarak algılanacak şekilde sunulabilmektedir. Başka bir ifadeyle okur yansız bir haber okuduğunu düşünürken aslında farkında olmadan yönlendirilebilmektedir.

Durur'un (2011, s.24) Goffman'dan (1974, s.21) aktardığına göre her çerçeve somut olayın belirlenmesi, kavranması ve adlandırılması için olanaklar vermektedir. Bu anlamda çerçeveleme bir yorumlama şemasıdır. Yorumlama, edebi bir metinde, bir sanat çalışmasında zaten olması beklenen, problem teşkil etmeyen bir uygulamadır. Bununla birlikte basının var oluş amacı gerçekliği ayna gibi yansıtmaktır. 5N 1K (Kim, Ne? Nerede? Ne Zaman? Nasıl? Neden?) sorularının yanıtlarını aktarıp, konunun birden fazla muhatabı varsa her birine ct/cm olarak eşit oranda yer verip sade bir dil ile haber metni yazılmalıdır. Yorum, okura bırakılmalıdır. Ancak uygulamada bu ilkelere sadık kalınmadığı görülmektedir. 
Haberde yorum, manipülasyon anlamına gelmektedir ve etik olarak sorgulanmaya muhtaç bir durumdur. Çerçeveleme yaklaşımının iletişim araştırmalarında önem kazanmasının nedeni yukarıda ifade edilen "yorumlama şeması" kavramıdır. Çerçeveleme yaklaşımı haber değeri taşıyan bilginin okur/izler kitleye ulaşıncaya kadar uğradığı anlam değişimini saptamaya imkân tanımaktadır. Scheufele ve Tewksbury'ye göre çerçeveleme, herhangi bir konunun haber metninde biçimlendirilme şeklinin izleyicilerin algılamalarını etkileyebileceği varsayımına dayanmaktadır (Scheufele, 2007, s.11). Yaşanmış olan somut gerçeklik, haberin çerçeveleniş biçiminde göre yeni bir yorum kazanır. İzleyici algılamasının istenilen doğrultuda şekillenmesi, söz konusu medya organına, türüne göre tiraj, reyting artışı getirmektedir. Bunun anlamı da reklam/ilan verenler için cazip hale gelmektir.

Araştırmada çerçeveleme yaklaşımının yanı sıra söylem analizinden de yararlanılmıştır. Çünkü Haberin çerçeveleniş biçimi ile yapılan manipülasyonun derecesini tespit etmek için haber metninin tamamının da incelenmesi gerekmektedir. Ayrica spotta yer alan ifadelerin alt metinleri, yan anlamları ile ilgili bir değerlendirmede bulunabilmek için söylem analizine gerek görülmüştür. Söylem analizi, herhangi bir metinde inşa edilen söylem ile söylemin içinde üretildiği toplumsal-kültürel yapı arasındaki ilişkilerin incelenmesine imkân tanımaktadır. "Söylem analizi, metni sözdizimsel ve semantik sınırların ötesine giderek bir yapı söküme uğratma ve onu kuran niyetin ne olduğunu anlama çabasıdır" (Solak, 2011:3). Temsili pratikler aracılığıyla belirli bir konuya ilişkin anlamlı bilgilerin üretildiği söylemler inşa edilir" (Düzgit, 2011, s.55). Konu gazetecilik mesleği bağlamında ele alındığında, toplumun genelini ilgilendiren ve haber değeri taşıyan bir gelişme gazetenin genel yayın politikasına göre yeniden kurgulanılarak yeni bir anlam üretilmektedir. Söylem analizinin de kendi içinde farklı metotları bulunmaktadır. İletişim araştırmalarında genellikle eleştirel söylem analizi tercih edilmektedir. "Eleştirel söylem çözümlemesi yapanlar arasında TeunvanDijk'ın önerdiği model, haber söylemi aracıllğıyla üretilen toplum-bilişsel yapılanmayı araştırmıştır. Van Dijk, özellikle haber metinlerinde söylem içinde yeniden inşa edilen iktidar, güç, egemenlik, ideoloji ilişkilerini, dilbilimsel kavramlar ve dilsel yapıları kullanarak incelemektedir" (Karaduman, 2017, s.33). Bu noktada tarafsılık, 
doğruluk, dengelilik gibi temel gazetecilik ilkeleri de sorgulanmaya açılmaktadir.

"Söylem analizi, metnin anlamıyla yani 'metin ne hakkında ve ne söylemek istiyor ile' ilgilenmektedir. Böylelikle metin içeriğinde gizli kalan yan anlamların da çözümlenmesi sağlanmış olur. Söylem analizinin metnin aktardıklarını, ideolojik boyutuyla birlikte anlaşılabilmesi için, toplumsal, kültürel, siyasal ve ekonomik bağlamlarıyla ele alınması gerekmektedir. Bu ilişkiler ağı içerisinde haber, yapılandırılmış bir toplumsalkültürel söylem olarak ele alınmaktadır" (Cangöz, 1999, s.85). Toplumsal ön kabuller, ön yargılar, kültürel yapıda zamanla meydana gelen değişimler, yeni iletişim teknolojilerinin sunduğu yeni ifade biçimleri gibi pek çok sosyal-kültürel değişken, habere konu olan gerçeklik ile haberde inşa edilen söylem arasında farklılıklara zemin hazırlamaktadır. Konunun bir boyutu medya kurumları, bir boyutu da toplumsal kültürel yapıdır. Medya kurumları cephesinde genel yayın politikaları, reklam-ilan verenler ile ilişkiler gibi unsurlar haber metnindeki söylemi etkilemektedir.

Araştırmada Milliyet, Habertürk ve Posta gazetelerinin internet sitelerinde yer alan haberler örneklem olarak kullanılmıştır. Amaçlı örnekleme ile seçilen haberler, gazetelerin arama sekmesine "Kıvılcım Ural" "Seçkin Piriler" "Kaan Tangöze" isimleri yazılarak bulunmuştur. Bu tarama ile ulaşılan haberlerin tamamı incelenmekle birlikte bu araştırma kapsamına 15 örnek haber dâhil edilmiştir.

\section{Bulgular}

Bu kısımda Seçkin Piriler-Kaan Tangöze-Kıvılcım Ural ilişkisi konusunda Milliyet, Sabah ve Posta gazetesinde yayınlanan haberlerden oluşturulan örneklem çerçeveleme yaklaşımı ve söylem analizi yöntemi ile değerlendirilecektir.

\section{1. Örnek Haber}

Milliyet Gazetesi-11.12. 2016

Başlık: Kıvılcım Ural, Duman'ı Dağıttı!

Alt Başlık: Duman'ın solisti Kaan Tangöze ile aşk yaşayan Kıvılcım Ural, Duman grubunun işlerine karışınca grup karıştı. 


\section{Analiz:}

Haberin başlı̆̆ı "Kıvılcım Ural, Duman'ı dağıttı!" şeklindedir. Başlıkta kadın doğrudan tek özne olarak kullanılmıştır. "Dağılma" durumunun sorumlusu yalnızca kadın olarak sunulmaktadır. Başlıkta ilk anlam olarak "Duman grubunun dağılması"; ikinci anlam olarak da medyada sürekli işlenen "Dağılan yuva"ya gönderme söz konusudur ve bu iki durumun tek faili de doğrudan doğruya kadındır. Haber metni incelendiğinde Kıvılcım Ural'ın Duman grubunun işlerine karışmaya başladığı ve grubun bateristi Cengiz Baysal'ın bu duruma isyan ederek gruptan ayrıldığı bilgisi verilmektedir. Bu bilginin kaynağını öğrenmek için haber metni incelendiğinde ise "İddiaya göre" ifadesi ile karşılaşılmaktadır. Bateristin ayrilma nedeninin gerçekten Kıvılcım Ural olup olmadı̆̆ı net bir kaynağa dayanmamaktadır. Buna rağmen başlık bu bilgiyi net ve kesin bir şekilde başlı̆̆a taşımışıır. Aldatma davranışının iki failinden biri, hatta evli olduğu için sorumluluk payı daha fazla olan Kaan Tangöze tamamen pasif, edilgen, masum, adeta konu ile ilgisiz bir temsil ile aktarılırken; aldatma davranışının diğer tarafı olan Kıvılcım Ural "Dağıtan" yegane taraf, tek sorumlu olarak temsil edilmiştir. Haberde yanlı/eril bir bakış açısı söz konusudur.

\section{2. Örnek Haber}

\section{Milliyet Gazetesi - 25.09.2016}

\section{Başlık: Seçkin benim düşmanım değil}

Alt Başlık: Manken Seçkin Piriler ile Duman grubunun solisti Kaan Tangöze'nin altı yıllık evliliğinin sona ermesine sebep gösterilen Kıvılcım Ural, Milliyet CADDE'ye konuştu

\section{Analiz:}

Haberin alt başlı̆̆ında "Kaan Tangöze'nin altı ylllık evliliğinin sona ermesine sebep gösterilen" ifadesi bulunmaktadır. Bu cümle doğrudan doğruya taraflı bakış açısını yansıtır niteliktedir. Öncelikle gazetenin, evliliğin sona ermesindeki tek sorumlunun kadın olduğuna ilişkin bir ön kabulü vardır. "...evliliğin sona ermesine sebep gösterilen.." ifadesindeki sebep göstermeyi kim yapmaktadır? Toplum 
mu? Bizzat aldatılan eş Piriler mi? Haberi yazan muhabir mi? Bu nokta belirsizdir ancak sanki toplumun genelinde böyle bir kabul olduğu algısı oluşturulmaktadir.

\section{3. Örnek Haber}

\section{Milliyet Gazetesi - 24.09.2016}

Başlık: Kaan Tangöze-Kıvılvım Ural ciftinden evlilik kararı!

Alt Başlık: Seçkin Piriler'in açıklamalarından birkaç saat sonra ortaya çıkan Kıvılcım Ural, Kaan Tangöze ile evlenme kararı aldıklarını söyledi.

\section{Analiz:}

Haberin alt başlığında "Seçkin Piriler'in açıklamalarından birkaç saat sonra ortaya çıkan" ifadesi yer almaktadır. Haber metni incelendiğinde aldatılan eş Seçkin Piriler' in bir TV programına katıldığ ve eski eşini özlediğini söylediği görülmektedir. Alt başlıkta ise Kivilcım Ural'ın bu açıklamadan hemen sonra "Kasıtlı" olarak "Ortaya çıtıı̆̆ı" ön kabulü aktarılmaktadır. Üstelik gerçekten kasıtlı olarak "Ortaya çıkmış" olsa bile onu gören muhabirler kendisine "Ufukta evlilik var mı?" sorusunu yöneltmişler ve o da bu soruya cevap olarak evlenmeye karar verdiklerini söylemiştir. Haberde yine olayın kadınları ön planda, aldatma davranışının diğer sorumlu yarısı olan erkek pasifledilgen konumdadır, adeta yok hükmündedir.

\section{4. Örnek Haber}

Milliyet Gazetesi - 04.08.2017

Başlık: Duman konserinde gergin anlar

Alt Başlık: Duman Grubu önceki akşam Harbiye Açıkhava Tiyatrosu'nda konser verdi Haber Görseli:

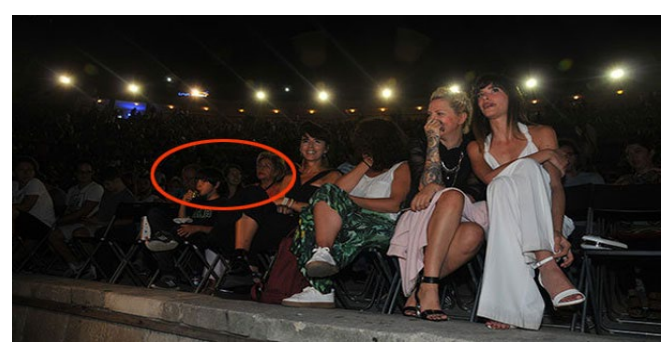




\section{Analiz:}

Haberin başlı̆̆ı "Duman konserinde gergin anlar" şeklindedir. Gerginliğin nedenini öğrenmek için haber metni incelendiğginde konsere gelenler arasında Tangöze'nin anne ve babasının da olduğu, ancak Kivilctm Ural'ın onlara merhaba bile "Diyememiş" olduğunun yazıldığı görülmektedir. Haber metninde "Ailesiyle aramız çok iyi" diyen Kıvılcım Ural, Tangöze çiftine 'Merhaba' bile diyemedi" cümlesi vardır ve başlıkta belirtilen "Gerginlik" nedeni olarak bu gösterilmektedir. Öncelikle "Merhaba diyemedi" ifadesi taraflıdır ve yargı içermektedir. Bu cümlenin al metninde "Merhaba demek istedi, ancak suçluluk duygusu, utanma, sevilmeme, kabul edilmeme vs. nedenlerle diyemedi" ön kabulü yatmaktadır. Konser öncesinde selamlaşmış olabilecekleri, birbirlerini görmemiş olabilecekleri (Haber görselinde birbirlerine çok yakın oturmadıkları görülüyor), ya da "Diyememek" değil de belki de kendisinin o an konuşmak istememiş, tercih etmemiş olabileceği ihtimalleri tamamen yok sayılmış ve kadın doğrudan "Sanık" koltuğuna oturtulmuştur.

\section{5. Örnek Haber}

\section{Milliyet Gazetesi - 24.12.2017}

Başlık: Kıvılcım Ural özür diledi: Tek suçlu...

Alt Başlık: Seçkin Piriler'in ayrıldıklarını iddia ettiği Kaan Tangöze ile Kıvılcım Ural, eleştirilere kulaklarını tıkayıp aşklarını yaşamaya devam ediyor..

\section{Analiz:}

Haberin başlı̆ğ " Kıvılcım Ural özür diledi: Tek suçlu..." şeklindedir. Başlıkta "Özür" ve "Suçlu" kavramları yer almaktadır. Bu konu yaklaşık bir buçuk yıldır haber medyasının gündemindedir ve takip eden okur aldatma konusunu bilmektedir. Medyanın sunumu da analizin detaylı şekilde ortaya koyduğu üzere "Yuva yıkan kadın", "Edilgen, kandırlan erkek" dili üzerinden inşa edildiği için aldatma suçunun tek faili kadın algısı zaten oluşmuştur. Bu ön kabulü destekler nitelikte "Kıvılcım Ural özür diledi: Tek suçlu.." şeklinde Ural'ın suçlu olduğunu kabul ettiği ve özür dilediği izlenimi dil üzerinden oluşturulmaktadır. Oysa haber 
metninin tamamı incelendiğinde başlıkta dil üzerinden yaratılan manipülatif alginın gerçeği anlaşılmaktadır: Ural'ın özür dilediği konu bu aldatma olayı ile hiç bir ilgisi olmayan, 17 yaşındayken yaşadığı bir olay ile ilgilidir. Özür de, suç da aldatma olayı ile tamamen ilgisizdir. Ancak başlıkta bilinçli bir yönlendirme söz konusudur.

\section{6. Örnek Haber}

\section{Milliyet Gazetesi - 13.12.2017}

Başlık: Kıvılcım Ural'dan nispet paylaşımı!

Alt Başlık: Eski manken Seçkin Piriler ile Duman grubunun solisti Kaan Tangöze'yle evliliğinin bitmesine neden olan Kıvılcım Ural'ın keyfi yerinde...

\section{Haber Görseli:}

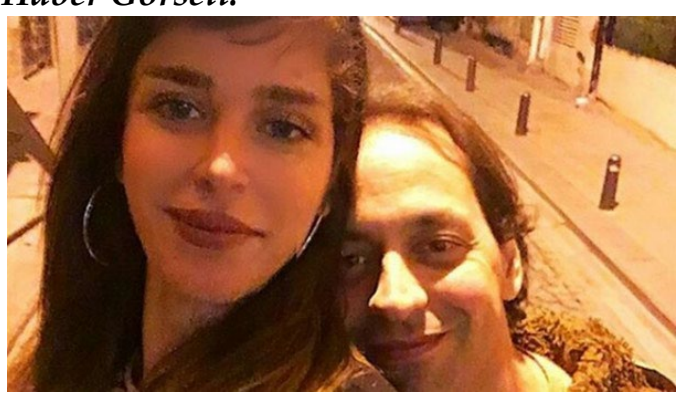

\section{Analiz:}

Haberin başlığı "Nispet paylaşımı!" şeklinde atılmıştır. Gazete adeta niyet okumakta ve bu paylaşımın gerekçesinin "Nispet yapmak" olduğunu net bir dil ile duyurmaktadır. Dilin imkan verdiği ölçüde tarafsız olması beklenen gazetecilik mesleği ile, meslek ilkeleri ile örtüşmeyen bir yaklaşım sergilenmiştir. Niyet okuması yapmak değil haber dilinde, her türlü iletişim biçiminde olmaması gereken bir davranıştır. Alt başlık ise aldatma suçunun tüm yükümlülüğünü doğrudan doğruya kadına yükler niteliktedir. "Seçkin Piriler ile Duman grubunun solisti Kaan Tangöze'yle evliliğinin bitmesine neden olan Kivnlcım Ural" cümlesi, suçun yarı yarıya sorumlusu, hatta bir başkasıyla nikah akdi bulunduğu için belki daha fazla sorumlusu olan erkek tamamen edilgen, başkası tarafindan "Aklı çe- 
linmiş" bir konuma yerleştirilirken, suçun diğer yarıdaki tarafı Kıvılcım Ural haber dili üzerinden tek suçlu ve sorumlu ilan edilmiştir. Üstelik "Keyfi yerinde" denilerek de "Yuva yıkan fettan kadın" stereotipi yeniden inşa edilmiştir.

\section{7. Örnek Haber}

\section{Milliyet Gazetesi 18.11. 2017}

Başlık: 'Umarım bir daha evli erkeklere bulaşmazlar'

Spot: Şarkıcı Yeşim Salkım'la özel bir kanalda magazin gündemini yorumlayan eski manken Seçkin Piriler, önceki akşam Nişantaşı Atiye Meyhane'deydi. Piriler, Yeşil Salkım'ın geceye katılacağını ancak anneannesinin hasta olması nedeniyle gelemeyeceğini söyledi.

\section{Analiz:}

Haberde bir kişinin açıklamasından bir cümle alarak bunu başlık olarak kullanmak mümkündür. Bu cümlenin açıklamanın ana fikrini, özünü yansıtır nitelikte olması gerekmektedir. Bir açıklamadan seçilen cümle başlık yapılacaksa burada tarafsızlığın sağlanması için açıklamayı yapan kişi de başlıkta belirtilmelidir. Örneğin: Manken Seçkin Piriler: Umarım bir daha evli erkeklere bulaşmazlar" şeklinde atılacak bir başlık, tarafsızlık kriterine daha çok yaklaşmıştır. Ancak ifadenin söylemi belirtilmeksizin doğrudan cümle başlık olarak kullanılmışsa burada gazetenin demecin sahibi ile ayn görüşte olduğu, ondan yana olduğu ve onun lehinde bir kamuoyu oluşturmak istediği sonucuna varılabilir. Konu bu haber özelinde ele alındiğında ikinci yaklaşımın tercih edildiği görülmektedir. Aldatma suçunun tek faili olarak kadın konumlandırılmış, erkek yine pasif, edilgen, "Bulaşılmış" taraf olarak temsil edilmektedir. Bir kadınla olan nikah akdini çiğneyen erkekten hiç söz edilmemekte, onun sorumluluk payı tartışmaya açılmamakta "Evli erkeklere bulaşarak yuvayı dağıtan kadın" yerleşik algısı örnek olayların haber ediliş biçimleri ile tekrar tekrar inşa edilmektedir.

\section{8. Örnek Haber}

\section{Milliyet Gazetesi - 05.01.2018}

Başlık: Yuva kesmedi, Duman'ı dağıtacak!

Spot: Duman Grubu'nun solisti Kaan Tangöze'nin sevgilisi Kıvılcım Ural 
yine rahat durmadi. Bu kez Duman Grubu'nun gitaristi Batuhan Mutlugil'in eşi Leyla Mutlugil ile kavga etti.

\section{Analiz:}

Haberin başlığı "Yuva kesmedi, Duman'ı dağıtacak" şeklinde atılmıştır. Başlık aldatma suçunun tek failini doğrudan doğruya kadın olarak temsil etmektedir. Var olan "Yuva yıkan kadın" kalıbını destekler ve yeniden inşa eder nitelikte bir çerçeveleme yapılmıştır. Erkek yine tamamen geri planda, geri planda bile değil, hiç yok; pasif edilgen, iradesiz, iradesi dışında bir kadın tarafindan aklı çelinen taraf olarak sunulmuştur. Üstelik başlıkta aynı pasiflik ve "Yıkıcı kadın" temsili bu sefer yuvanın yanı sıra Duman grubu için de tekrarlanmaktadır. Duman grubunu da dağıtacak olduğu net bir şekilde ifade edilmektedir. Iletişim, sözcükteki "Ş" harfi ile de kendini ortaya koyduğu gibi "İşteşlik" içeren bir fiildir. İkili ilişkilerden kitle iletişimine kadar her türlü iletişim karşıllklıdır. Bununla birlikte haber metinleri cinsiyet eşitliğinin gözetilmesi gereken konularda erkeği daima suçsuz veya haklı gören toplumsal ön kabuller desteklenir nitelikte yazılmaktadır. Haber dilinde yalnizca kadın suçlanmakta ve erkek masum ve iradesiz bir pozisyonda adeta korunmaktadır. Yillarca Türk sinemasında da bir stereotip olarak pek çok filmde kilit rolde yer alan "Fettan kadın" imgesi, haber çerçevelemesi ve dili ile beslenmektedir. Haberin spotu incelendiğinde bu manipülatif yaklaşımın devam ettiği görülmektedir. "Kivilcım Ural yine rahat durmadı" cümlesinde "Ural önce de rahat durmamıştı. Bir yuvayı yıkmıştı. Rahat durmamak onun yinelenen, alışkanlık haline gelmiş davranışıdır. Bu davranışını bu sefer müzik grubunu dağıtarak yineledi" alt metni yer almaktadır. Görüldüğ̈̈ gibi iletişim sürecinin diğer bütün muhatapları iradesiz, pasif, herhangi bir davranış sergilemeyen yaptdadır; suç içeren tüm yıkıcı davranış ise sadece "Yıkıcı kadın" a aittir. Haber spotunda Ural'ın Duman grubu gitaristinin eşi ile kavga ettiği bilgisi bulunmaktadır. Ural bir kişiyle kavga etmiştir. Başka bir ifadeyle kavga davranışı da tek taraflı olarak bizzat "Yıkıcı kadın" Ural tarafindan sergilenmiştir. Olayın ayrıntıların öğrenmek üzere haber metni incelendiğinde Kıvılcım Ural'ın muhatabına ne söylediğine ilişkin hiç bir bilgi yer almamakta sadece "Kıvllctm Ural Türkçe dersi vermeye kalkıştı" şeklinde haber dili tarafsızlğ̆ına son derece uzak bir ifade bulunmaktadır. Kavganın diğer tarafı olan kişinin ise "Lolita ă̆zımı açtırma benim. Aslında senden oyunculuk dersi almak lazım. Bana sataşma, zaten rezil oldun. 
Seviyemiz ayn değil. Belirsiz tip seni" gibi aslında çok daha saldırgan ve "Kavga" tanımına uyar içerikte bir ifadede bulunduğu görülmektedir.

\section{9. Örnek Haber}

\section{Milliyet Gazetesi - 11.12.2018}

Başlık: Kıvılcım Ural çıldırdı! Savcılığa başvurdu

Spot: Geçtiğimiz günlerde Duman grubunun solisti Kaan Tangöze ile dünyaevine giren Kıvılcım Ural, hamileyken daha hassas olduğunu öne sürerek, yapılan hakaretlerden dolayı üzüldügünü belirtti ve savcılığa başvuruda bulundu.

\section{Analiz:}

Haberin başlığı "Kıvılcım Ural çıldırdı! Savcılığa başvurdu" şeklindedir. Öncelikle bir hukuk devletinde yaşayan ve herhangi bir suça maruz kaldığını düşünen her vatandaşın Savcılı̆̆a başvurma hakkı vardır. Savcılığa başvurmak ve "Çıldırmak" arasında bir bağlantı yoktur. Savcilığa başvuru gerekçesini öğrenmek üzere spota bakıldığında hamile olan Ural'ın bu dönemde daha hassas olduğu ve kendisine yapılan hakaretlerden dolayı üzüldüğü bilgisine ulaşılmaktadır. Hakaret bir suçtur ve hamilelik gibi özel bir durumu olsun olmasın, bu suça maruz kalan herkesin hukuk nezdinde hakkını araması olağandır. Üstelik hamilelik süreci gerçekten de hormonal değişimlerden dolayı duyarlı̆̆ın arttığı ve ne olursa olsun daha özenli davranılması gereken bir dönemdir. Bu nedenle Ural'ın Savcilı̆̆a başvurmuş olmasl, manipülatif başlıkta olduğu gibi "Çıldırmak!" sözcü̈̆̈̈ ile yansttılacak bir davranış değildir. Burada yine toplumda var olan "Fettan kadın" stereotipini besleyen ve tekrar inşa eden bir taraflı yaklaşım söz konusudur.

\section{0. Örnek Haber}

Sabah Gazetesi - 24.12.2017

Başlık: Kıvılcım Ural özür diledi! Haber Görseli:

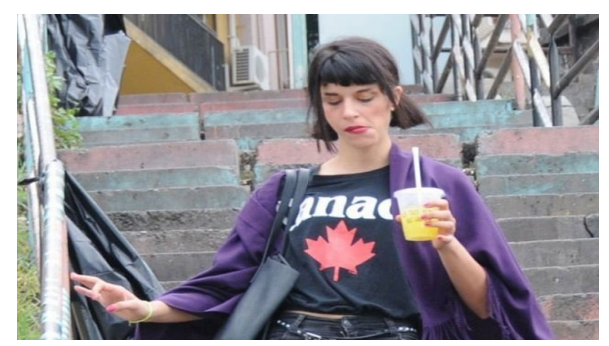




\section{Analiz:}

Haberin başlığı "Kıvılcım Ural özür diledi!" şeklindedir. Mesele bir yılı aşkın süredir yazll ve elektronik basının gündeminde olduğu için ilgi duyan okurlizler kitle konuyu bilmektedir. Olayın başlangıcından beri aldatma davranışının tek sorumlusu Kıvilcım Ural olarak temsil edilmektedir. Aldatmanın diğer tarafi Kaan Tangöze adeta yok hükmündedir. Bu eksende oluşturulan zihinsel alt yapr üzerinde bu başlı̆̆ın okur/izler kitleyi doğrudan "Kıvılcım Ural yuva yıkma suçunun tek failidir ve bu suçunu kabul ederek özür dilemiştir" anlamına ulaştıracağı açıktır. "Suçlu fettan kadın" stereotipi suçunu kabul etmiş ve özür dilemektedir. Aldatma sonucu biten evliliklerin tek suçlusu kadının bu şekilde nedamete gelmesi, okur nezdinde bir rahatlama sağlayacaktır ve öfke duygusunu tatmin edecektir. Oysa haber metni incelendiğinde Kıvılcım Ural'nn dilediği özürün aslında aldatma-biten evlilik konusu ile hiç bir ilgisi olmadığı anlaşılmaktadır. Ural 17 yaşındayken yaşadığı bir olayı anlatırken neden olduğu yanlış anlaşılmadan dolayı özür dilemektedir. Haber başlığı kasıtlı bir manipülasyon içermektedir. Haberin çerçevelenmesindeki bir diğer unsur da kullanılan görsellerdir. Foto muhabir, bizzat çektĭ̆i fotoğraf ile veya arşiv fotoğraflarından yapılan seçim ile de okur/izler kitle nezdinde bir algı inşası gerçekleştirebilir. Bu fotoğrafta Ural gözleri öne eğik, dudakları eğri bir şekilde çıkmıştır. Yüz ifadesinde ve beden dilinde dudaklarm ifade ettiği bir umursamaz tavrn yanı sira gözlerin ifade ettiği bir mahcubiyet de yansımaktadır. Fotoğraf bir "Anı yakalama işidir". Fotoğraf, yakalanan o "An" ile gerçeklik bağlamından tamamen farklı bir izlenim sunmaya imkân tanıyan bir sanattır. Bu haberde de istenseydi Ural'ın daha düzgün çıktı̆̆ı, objektife baktığı bir fotoğraf seçilebilirdi. Zaten bu konu ile ilgili haberlerin görselleri incelendiğinde "Fettan kadın" stereotipi olarak habere özne olan Kıvılcım Ural'ın ya güzel, derli toplu çıkmamış fotoğrafları ya da arşivden seçilen kırmızı rujlu, hafif dekolte fotoğ raflarıdır.

\section{1.Örnek Haber}

Sabah Gazetesi - 29.03.2017

Başlık: Kıvılcım suçsuz sorumlu benim!

\section{Analiz:}

Haberin başlığı medyanın konu ile ilgili taraflı yaklaşımına aldatma davranışının 
diğer yarısı olan Kaan Tangöze'nin isyanını yansıtır niteliktedir. Konu gündeme geldiğinden beri demeç vermeyen; diğer taraftan gazetecilerin de Kivılcım Ural kadar üstüne gitmediği Kaan Tangöze ilk kez konuşma ihtiyacı hissederek: "Evliliğimin sona ermesi ve bunun sebepleri konusunda haksız açıklamalar yapılıyor. Kıvılcım' ın üzerine baskı kurulmasından rahatsızlı duyuyorum. Özel hayatımla ilgili tüm sorumluluk bana aittir" açıklamasını yapmıştır. Aldatma davranışının görmezden gelinen tarafı Kaan Tangöze de medyanın taraflı tutumunun farkındadır ve Kıvılcım Ural'ın üzerindeki medya baskısına dikkat çekmektedir.

\section{2. Örnek Haber}

\section{Sabah Gazetesi - 15.12.2017}

Başlık: Kıvılcım Ural sevgilisi Kaan Tangöze ile nispet yapmaya doyamad1!

Alt Başlık: Seçkin Piriler'in, Kaan Tangöze ile evliliğinin bitmesine neden olan Kivılcım Ural'in keyfi yerinde

\section{Haber Görseli:}

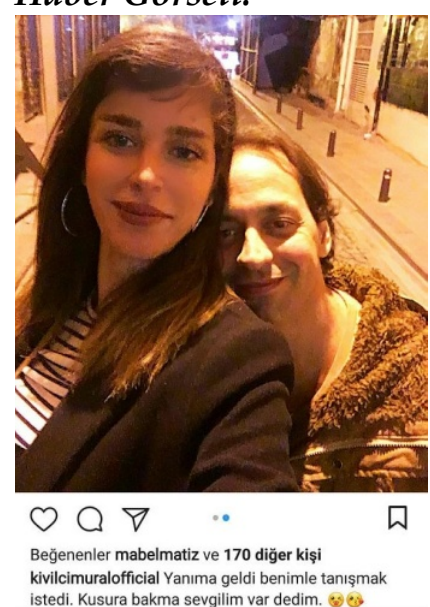

\section{Analiz:}

Haberin başlı̆̆ı "Kıvılcım Ural sevgilisi Kaan Tangöze ile nispet yapmaya doyamadı!" şeklinde atılmıştır. Başlığın alt metninde okura "Kıvılcım Ural yuva yıkan kadındır. Yuva, aile gibi kutsal değgerler onun için bir şey ifade etmemekte, bir kadının elinden aldığı erkekle zaferini kutlamayı ve başta mă̆dur kadın olmak 
üzere herkese nispet yapmayı önemsemektedir" önermesi sunulmaktadır. Okur kitlesi de zaten kadına biçilen toplumsal roller ve erkeğe biçilen toplumsal roller konusunda erkek lehine bir duruş sergileyen kültürel yapının içinden geldiği için bu tip bir okumaya yatkındır ve bu haber çerçevelemesinin okurda karşıllı̆̆ vardır. Gazete, attı̆̆ı başlık ile niyet okuması yapmaktadır. Kıvılcım Ural bu fotoğrafi sosyal medya hesabında nispet yapmak -yuva yıkan 'fettan kadın'lara özgü kötücül duygularını açı̆̆a vurmak için paylaşmıştır. Oysaki artık sosyal medya hayatın ayrılmaz bir parçası durumuna gelmiştir ve herkes hayatının her anını kitlesiyle paylaşarak var olmakta, ya da var olduğunu hissetmektedir. Bu nedenle sosyal medya paylaşımlarının ardında tek bir motivasyon aramak gazetecilik tarafsızlı̆̆ı ile uyuşmayan bir yaklaşımdır, kasıtlı bir manipülasyondur. Haberin alt başlığında da aynı tarafl yaklaşım devam etmektedir. Alt başlıktaki "Seçkin Piriler'in, Kaan Tangöze' yle evliliğinin bitmesine neden olan Kıvılcım Ural" ifadesi yeterince açıktır. Evliliğin bitmesinin tek sorumlusu, tek suçlusu vardır: Kıvılcım Ural. Bir kadınla nikâh akdi olan Kaan Tangöze pasif, edilgen, iradesiz, başka bir kadına aitken kendi rızası dışında başka bir kadın tarafından "Ayartılarak" evliliği bitmiş taraf olarak sunulmakta ve adeta erkek egemen tarafl medya dili tarafindan korunmaktadır. Oysa fotoğrafa bakıldı̆̆ında Kaan Tangöze'nin de Ural ile birlikte olmaktan mutlu olduğu görülmektedir. Haber başlığı ile alt başlı̆ğ ile taraflı ve kadın aleyhinde, erkek korumacı bir çerçeveleme ile okura sunulmaktadır.

\section{3.Örnek Haber}

\section{Posta Gazetesi - 05.01.2018}

Başlık: Kıvılcım Ural yine kavga etti

Spot: Duman Grubu'nun solisti Kaan Tangöze'nin sevgilisi Kıvılcım Ural yine rahat durmadi. Bu kez Duman Grubu'nun gitaristi Batuhan Mutlugil'in eşi Leyla Mutlugil ile kavga etti

\section{Analiz:}

Haberin başlı̆̆ı "Kıvılcım Ural yine kavga etti" şeklinde atılmıştır. Başlık ile okurda oluşması istenen anlam açıktır: "Ural sürekli kavga eden kötücül bir karakterdir. Yuva yıkan kadındır ve yuvasını yıktığı kadın ile de kavga etmektedir. Bu alışkanlığın yine tekrarlamıştır". Haber başlı̆̆ı ile aldatma davranışının tek suçlusu olarak konumlandırlan kadın, bir kez daha okur nezdinde günah keçisi 
ilan edilmekte ve "Kötülü̈̆̈̈̈ne" vurgu yapılmaktadır. Haberin spotu incelendiğinde de yine Ural için "Rahat durmadı", "Kavga etti" gibi haber dilinde olmast istenen tarafsızlıktan çok uzak ifadeler ile karşılaşılmaktadır. Metin doğrudan doğruya kadını yargılar, suçlar ve tek sorumlu olarak bir kez daha ilan eder niteliktedir. Haber metninde de "Ural Türkçe dersi vermeye kalkıştı" gibi yine tarafsızliktan çok uzak, yargılayıcı bir dilin devam ettiği görülmektedir. Sosyal medyanin birbirine hakarete varan ifadelerin stradanlaştı̆̆l, rutin hale geldiği bir mecra olduğu ve her gün yüzlerce bu tip içerikte yorumlar yapıldığı düşünüldüğ̈̈nde özellikle Ural'ın "Ders vermeye kalkıştı" şeklinde ayıplanması haberin taraflılı̆̆ını yansıtmaktadır. Üstelik haberde Ural'ın muhatabı olan kişinin çok daha ağır hakaret içeren ifadeler kullanmış olması hiç bir şekilde ayıplanmamış, yargılanmamiştır.

\section{4. Örnek Haber}

\section{Posta Gazetesi - 03.01.2018}

Başlık: Kıvılcım Ural'dan takipçisini şoke eden cevap!

Alt Başlık: Duman grubunun solisti Kaan Tangöze ile ilişkisinde sorunlar yaşadığ 1 iddia edilen Kıvılcım Ural, bu kez bir takipçisine verdiği yanıtla gündeme geldi

\section{Haber Görseli:}

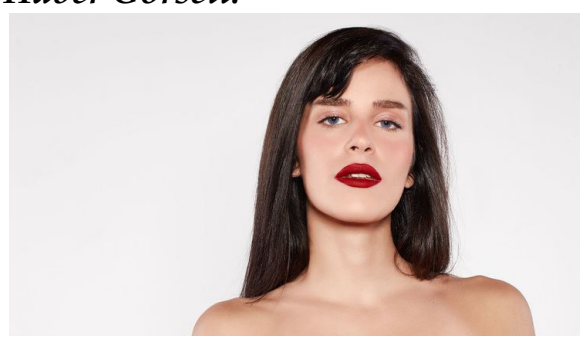

\section{Analiz:}

Haberin başlı̆̆ı "Kıvılcım Ural'dan takipçisini şoke eden cevap!"tır. Başlıkta yine Ural ile bir takipçisi arasındaki iletişim, yani iki tarafı olan, işteşlik içeren fiil; tek tarafa indirgenmiş ve Ural mercek altına alınmıştır. Üstelik başlıktan anlaşıldığı üzere Ural cevap veren tarafttr. Yani "Şoke eden" ifade her ne ise, kendisine yönelik bir ifadeye yant olarak verilmiştir. Haberin Ural merkezli monolog olarak 
sunduğu diyaloğun ne olduğunu öğrenmek üzere haber metni incelendiğinde haber başlığı ile sunulanın aksine hakarete uğrayan, sözlü saldırıya uğrayanın Ural olduğu anlaşılmaktadır. Bir takipçisi Ural'a "Yav he he, zavall yaratık seni. Senin yüzünden Duman'dan soğudum" gibi ağır ifadelerle sataşmıştır. Ural da bu saldırıya ve hakarete cevap olarak "Duman da bayılıyor sana. Çok ağlıyor sen yoksun diye" sözlerini sarf etmiştir. Her iki ifade karşılaştırıldığında "Şık" olarak adlandırılacaksa eğer, bu tabiri takipçinin ifadesine yakıştırmak çok daha adil olacaktır, çünkü "Zavall yaratık" gibi hakaret sözleri içermektedir. Ural'ın ona verdiği yanıt nispeten daha ölçülüdür. Ancak haber öyle bir şekilde çerçevelenmiştir ki, sanki ölçülü olan taraf Ural'ın muhatabı, şok eden cevap ile ölçüyü kaçıran taraf Ural'dır. Haberde görsel kullanımının da haberin çerçevelenmesinde önemli unsurlardan biri olduğu yukarıda belirtilmişti. Bu haberde de Ural'ın kırmızı rujlu, dekolte bir fotoğrafi tercih edilmiştir. Bu görsel de "Fettan kötücül kadın" stereotipini destekler niteliktedir.

\section{5. Örnek Haber}

Posta Gazetesi - 23.12.2017

Başlık: Kıvılcım Ural: 'Kötü kadın' değilim, bu hikâyede suçlu varsa o da aşk

Spot: Seçkin Piriler ve Kıvılcım Ural birbirine girdi. Duman'ın solisti Kaan Tangöze suskunluğunu bozmadı. Çocuklar arada kaldı. Ve bu aşk üçgeni son zamanların en çok konuşulan olayı oldu. Kıvılcım Ural her şeyi Posta Gazetesi'nden Işıl Cinmen'e anlattı

Haber Görseli:

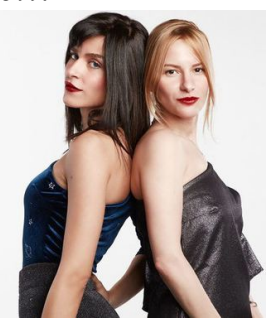




\section{Analiz:}

Haber, gazeteci Işıl Cinmen'in Kıvılcım Ural ile yaptı̆̆ı röportajdır. Bu röportaj, konu ile ilgili olarak bugüne kadar çıkan haberler içinde aldatma davranışında tek suçlunun kadın olmadığı, erkeğin de yarı yarıya pay sahibi olduğu, hatta evli olanın erkek olması nedeniyle belki de sorumluluk payının daha fazla olduğu önermesine dikkat çeken 2. haberdir (İlki 29.03.2017 tarihli Sabah gazetesinde çıkan ve Kaan Tangöze' nin sözlerini içeren 'Suçlu benim' konulu haberdir. Haber ve analizi yukarıdadır). İki yılı aşkın süredir gündemde kalan ve hâla gündemi işgal eden bir konuda çıkan haberlerin yalnızca ikisinin tarafsız nitelikte olması hem gazetecilik mesleği açısından, hem de toplumsal açıdan üzerinde durmaya değer bir olgudur. Haberin başlığı o ana kadar sergilenen taraflı yaklaşıma bir isyan, bir tepki niteliğindedir: "Kötü kadın' değilim, bu hikâyede suçlu varsa o da aşk". 50'li-70'li yıllar arası Türk sinemasında yuva yıkan kadın stereotipi için halkın kullandığg "Kötü kadın" kalıp ifadesi, Ural için medya tarafından oluşturulmaya çalışılan imgenin özetidir. Konunun ne medya tarafi, ne de toplum tarafi biten evlilik ve yeni başlayan ilişki denkleminin tek bir tarafin tekelinde olmayacağı gerçeğini tartışma gereği duymamakta ve alışllmış şablona uyularak olumsuz tablonun bütün sorumluluğu kadının omuzlarına yüklenmekte ve kadın toplumsal öfke tatmininin odağı haline getirilmektedir.

\section{Tartışma ve Sonuç}

Örnekleme dâhil olan haberler incelendiğinde medyanın aldatma davranışının sorumluluğunu tamamen kadın tarafına yüklediği ortaya çıkmıştır. Araştırmaya sadece 15 haber dâhil edilmekle birlikte gazetenin arama bölümü aracılığı ile taratıldığında konu ile ilgili çıkan bütün haberler incelenmiştir ve yukarıdaki örnekleme dâhil edilen iki örnek haber (29.03.2017/Sabah, 23.12.2017/Posta) dışında aldatma davranışında erkek tarafının da sorumlu olabileceğini tartışmaya açan bir habere rastlanmamiştır.

Medyada kadına yönelik aleyhte temsiller sadece bugüne özgü ya da belli coğrafyalara özgü bir sorun değildir. Medyanın hayatın içinde tuttuğu yer arttıkça kadın temsili de sorgulanmaya muhtaç bir olgu olarak küresel ölçekte kendini göstermiştir. "Medyada kadın temsili yoğun ola- 
rak 1970'li yıllarda feminist medya çalışmaları aracılığıyla gündeme getirilmiş ve kadını ikincil konuma iten toplumsal süreçlerin medyadaki kadın temsilleri ile etkileşim içinde bulunduğuna dikkat çekilmiştir" (Çelenk, 2010, s.230). Medyanın kadın aleyhinde bir temsil sunması toplumsal-kültürel yapının dinamiklerinden bağımsız değildir. Dünya genelinde eşit iş yaptığı halde erkekten daha az maaş alma, liyakat sahibi olmasına rağmen karar alıcı konumlara getirilmeme gibi aleyhte tutumlara hâlâ rastlanmaktadır. Konu bu araştırma bağlamında değerlendirildiğinde toplumsal kültürel yapı içinde kalıp ifadeler olarak kullanılan "Yuva y1kan kadın", "Kötü kadın", "Arabozucu" cümleleri, aldatma konusunu işleyen haberlerde de sıklıkla yer almıştır.

Tarafsız olması beklenen gazeteler, iki sorumlusu bulunan aldatma davranışında sadece kadını sanık sandalyesine oturtmuştur. Haberde yapılan çerçeveleme ile adeta bir "Kötü kadın" stereotipi yeniden inşa edilmiş ve bu stereotip toplumsal-kültürel hafızada karşılık bulmuştur. "Metinlerin içerik kadar biçimsel özellikleri de dilin cinsiyet ayrımcılığını nasıl pekiştirdiğini örnekler. Seçilen isimler, sıfatlar. Etken ya da edilgen yapinın tercihi kadının toplum içindeki konumunu "doğal ve verili" görünmesini sağlayabilir" (Okan, 1998, s.190). Haberde kullanılan görseller, başlık, üst başlık, alt başlık ve spotlarda kullanılan ifadeler, iki kişi tarafından eşit şekilde paylaşılan ve toplumsal normlara uymayan bir davranış modelinin sorumluluğunu, suçunu sadece kadına yüklerken, erkeği görmezden gelerek adeta bir koruma kalkanı altına almaktadır. Bir konunun sunuş biçimi kadar, "sunulmayışı" da haber analizinde anlam ifade etmektedir. Medyanın erkek tarafına yönelik bu "görmeyişi" toplumsal ön kabulleri de yansitır niteliktedir. Zira toplumda aldatma davranışında erkek "aklı çelinmiş" pasif ve edilgen taraf olarak kabul edilirken; kadın "akıl çelici" etkin ve aktif taraf olarak kategorize edilmektedir. Medyada kadın temsili ve toplumsal-kültürel yapı arasındaki ilişki ile ilgili olarak Osmanlı Bankası Arşiv ve Araştırma Merkezi'nde bir konuşma yapan Prof. Dr. Sevda Alankuş (2009, internet sitesi) "..kadınların -kendi içinde bir takım tutarsızlıklar bulunmakla birlikte - belirli basmakalıplaştırmalar çerçevesinde temsil edildiklerini, bunun da ataerkil gündelik yaşam ilişkilerinin yeniden üretilmesi anlamında bir 'temsil (siyaset)i'ne karşılık geldiğini düşünüyorum" ifadelerini kullanmıştır. Alankuş'un ifade ettiği 'kadının belli 
basmakalıplaştırmalar çerçevesinde temsil edilme hali', çerçeveleme yaklaşımı ve söylem analizi ile değerlendirilen bu araştırmanın bulguları ile örtüşmektedir. "Çerçevelemek; algılanan bir gerçekliğin bazı yönlerini seçip onları bir iletişim metninde daha önemli hale getirerek belli bir problem tanımını, neden sonuç yorumunu, ahlaki değerlendirmeyi ve/veya çözüm önerisini destekleyecek biçimde kullanmaktır" (Entman 1993, s.52).

Toplumun tanıdığı ünlü bir çiftin aldatma ile sonlanan evliliği konusunda evli olduğu kadını aldattığı halde görmezden gelinerek temize ç1kartılan bir erkek ve onunla ilişki yaşayan kadının (başlıklarda, görsellerde, spotlarda, haber metninin içinde) ön plana çıkartılarak yargılandığı tespit edilmiştir. Haberde çerçevelemek "bir mevzu konuşulduğunda gündemi için belirli niteliklerin seçimi ve üzerine vurgu olarak haberleri göndericinin istediği gibi elemek ve şekillendirmek için kesme ve düzeltme gerçeği"dir(McCombs 2004, s.87). Seçkin Piriler-Kaan Tangöze-K1vılcım Ural ilişkisi konusunda içerik hem habercinin istediği gibi, hem de okur/izler kitlenin toplumsal-kültürel ön kabulleri doğrultusunda istediği gibi kesilmiş, düzeltilmiş, yeniden kurgulanmış ve tarafsız olması gereken haber dilinden tamamen uzaklaşılmıştır.

$\mathrm{Bu}$ araştırma konusu bağlamında medyanın cinsiyet eşitliği konusundaki erkek lehine taraflı tutumu net bir şekilde tespit edilmiştir. Aynı taraflı yaklaşım toplumda da var mı sorusu sorulduğunda Nuray Alagözlü'nün (2009, s.37-48) atasözleri ve deyimler üzerine yapmış olduğu araştırma aydınlatıcı olmaktadır. Atasözleri ve deyimler kültürel yapıyı, ön kabulleri yansitan en köklü toplumsal içeriklerdir. Alagözlü (2009, s.46), "Atasözleri ve deyimlerin aslında ideolojik bir söylem oluşturduğu söylenebilir. Kadın olgusu ile bağdaştırılan kavram alanlarının, dolayısıyla eğretilemelerin, olumsuz çağrışımlar yaratması ile kadını sınırlayan, önemsizleştiren, yer yer küçümseyen ve küçülten bir ideoloji sunulmaktadır" ifadelerini kullanmaktadır ve medyanın taraflı temsilinin okur-izler kitlede de bir karşılığı olduğunu doğrulamaktadır.

Konunun bir diğer sorunlu tarafı da medyanın okur/izler kitleyi habere çekerek tiraj-tıklanma-reyting oranlarını yükseltmek ve bununla doğru orantılı olarak reklam-ilan gelirlerini arttırmak için meslek ilkelerinden ödün vererek ilgili veya ilgisiz "güzel, dekolte kadın" fotoğrafı kullanma motivasyonudur. Araştırmaya konu olan örnek olayda kadının daha çok ön plana çıkartılmasında toplumsal ön kabuller ile uyumlu içerik üretme 
isteğinin yanı sıra, güzel kadının habere okuru ve dolayısıyla reklam vereni daha çok çekeceği düşüncesi de yatmaktadır. Konu ile ilgili örnekleme dâhil edilen gazetelerdeki tüm haberlerde ve bu araştırmaya dâhil edilen haberlerde Kaan Tangöze'nin fotoğrafı yok denecek kadar azdır. Bu konu ile ilgili gazeteci Hıncal Uluç da 23.12.2017 tarihli yazısında "İki kadın amazonlar gibi döğüşürken, asıl suçlu Kaan kıs kıs gülüyor olmalı.....Peki niye magazin sayfalarında ve eklerde Kaan yok da, genç ve güzel kadınlar var? Bu da soru mu Allah aşkına.. Kaan'ın resmine kim bakar ki?" ifadeleri ile basının meslek ilkelerinden uzak yaklaşımına dikkat çekmektedir.

Tarafsız, gerçeklik bağlamından uzaklaşmadan sade bir haber dili ile aktarılan bilgi metinleri yerine cazip görselleri olan, özetin özetini eğlenceli bir dil ile aktaran, duygulara hitap eden metinler tercih edilmektedir. Bu metinler de şüphesiz reklam verenler için daha çekicidir. Gazetelerin asıl muhatabı ise olması gerektiği gibi okurlar değil, reklam verenler haline gelmiştir. Okurlar, daha doğru bir ifade ile "müşteriler" reklam verenlere ulaşmada birer aracı durumuna indirgenmiştir. "Çerçeveleme yaklaşımında konunun bir özelliği öne çıkmakta ve çerçeveler bu özelliğe göre belirlenmektedir. Sonuç olarak medya kadın ve erkeğin eşit olarak rol aldığı ve aldatma gibi toplumsal normlar bağlamında olumsuz kabul edilen bir davranışı tamamen taraflı, kadının aleyhine olacak şekilde okurlarına sunmaktadır. 


\section{EXTENDED ABSTRACT}

\section{One of The Ethic Problems in The Media: Gender Discrimination Sample News Analysis from Tabloid Media \\ *

\author{
Özgehan Özkan
}

Trabzon University

The main problem of this research is to show through a sample news article how the press makes a presentation. Communication is a very wide spectrum, ranging from human being's communication with himself to mass communication. A part of this spectrum is also bilateral relationsmarriage communication. It is a problem which is described as cheating that one of the spouses starts to have a relationship with someone else before the marriage contract expires, and the person showing this behavior is considered guilty by social values. If the couple whose marriage has been damaged by cheating consist of persons who are known to the community, the issue is newsworthy. Does the press present the "cheating" theme in a neutral, balanced way and without adding any comment? Or does it adopt an attitude in favour of women or men? Does it ignore one of the partners, so to speak, put him/her under protection, by loading the whole of the crime on the other partner? The aim of the research is to find answers to these questions.

\section{Method}

In this study, framing approach and discourse analysis have been used. The framing approach is an approach that aims to reveal how the news constitutes the basic elements that the reader first perceives as main heading, heading, subheading, spot, image etc. and the extent to which the news adheres to the criterion of impartiality. It is not possible to determine what is real and what is fiction for readers who have not received an education for the media literacy. Moreover, due to the structural features of the language, a biased text can be presented so as to be perceived as a 
neutral text by the reader. In other words, while the reader is considering that he/she is reading an impartial news article, in fact, he can be manipulated involuntarily.

Commentary in news means manipulation and is a situation that should be questioned ethically. The framing approach allows us to determine to what extent the newsworthy information changes semantically until it reaches the reader/audience. The experienced reality gains a new interpretation according to the way the news is framed. The shaping of the audience's perception in the desired direction brings about an increase in circulation and rating according to the type/organ of media in question. This means that it becomes attractive for advertisers.

In addition to framing approach, discourse analysis has also been used in the study. Because it is necessary to examine the whole text of the news in order to determine the degree of manipulation with the framing style of the news. In addition, discourse analysis has been required in order to be able to make an evaluation about the sub-texts and connotations of the expressions in the spot. Discourse analysis allows to examine the study of the relations between the discourse constructed in any text and the socialcultural structure in which the discourse is produced. When this subject is taken into consideration in the context of the profession of journalism, a development that is of interest to the general public and that has a news value is reconstructed according to the general publication policy of the newspaper and produced a new meaning, and a new meaning is produced. Discourse analysis has also different methods in itself. Critical discourse analysis is generally preferred in communication research. Among the critical discourse analyzers, the model presented by Teun van Dijk has investigated the socio-cognitive structuring designed through the news discourse.

In this study, the news articles on the websites of Milliyet, Habertürk ve Posta newspapers have been used as sample. The news articles selected with purposive sampling method have been found by writing "Kıvilcim Ural" "SeçkinPiriler" "KaanTangöze" in the search tab of the newspapers. Although all of the news reached through this screening have been reviewed, only 15 samples have been included into this research. 


\section{Discussion and Conclusion}

When the news included in the sampling is examined, it has been revealed that the media completely puts the responsibility of the cheating behavior on the women's side. While only 15 news articles have been included into the study, all news articles related to the subject which are displayed when searched through the newspaper's search tab have been examined and, except for the two samples included in the above sampling (29.03.2017/Sabah, 23.12.2017/Posta), it has been seen that there is no news bringing forward that the male side could also be responsible for cheating behavior.

The newspapers, which are expected to be impartial, put only the woman in the defendant's chair in the cheating behavior for which, in fact, both of partners also have responsibility. The stereotype of a "Bad woman" was rebuilt by the framing in the news and this stereotype has found a response in the social-cultural memory. While images, headings, main headings, subheadings used in the news and expressions used in spots are putting the responsibility and crime of a behavior model which is equally shared by two partners and does not comply with sociological norms, they ignore the male partner and, so to speak, put him under a protection shield. Just like the way of presentation of a subject, its "nonpresentation" has a meaning in news analysis. This "ignorance" of the media for the male side also reflects the social pre-acceptances. In the cheating behavior, men are considered as "seduced", passive and inactive side, and, however, women are categorized as seducer and active by the society.

The content on the relationship between the Seçkin Piriler-Kaan Tangöze-Kıvılcım Ural has been completely removed, corrected, reconstructed and completely detached from the news language that should be impartial, as both desired by the journalist and as desired by readers/audiences in accordance with their social-cultural pre-acceptances.

In the context of this research, it is clearly determined that the media has a biased attitude towards gender equality in favour of men. When asked whether the same biased approach also exists in society, the Nuray Alagözlü's study (2009, p.37-48) on proverbs and idioms enlightens the matter. Proverbs and idioms are the most deeply rooted social content that reflects the cultural structure and pre-acceptance. Alagözlü (2009, p.46), 
the following expression: "It can be said that proverbs and idioms actually constitute an ideological discourse. Due to the fact that the concept areas associated with women's phenomenon and, hence, metaphors create negative connotations, an ideology that restricts, trivializes, disdains and humiliates women from time to time is presented.", and confirms that the biased representation of the media has a counterpart among the readers.

Instead of information texts conveyed with a simple news language which are neutral and not detached from the reality context, texts that contain attractive images, convey the summary of the summary with an entertaining language and stimulate emotions are preferred. Undoubtedly, these texts are more attractive for advertisers. As a consequence of that, the main addressee of the newspapers has become advertisers but the readers as it should be. Readers, or, with a more accurate expression, "customers" are reduced to an intermediary role in accessing to advertisers. In the framing approach, one characteristic of the subject comes to the fore and frames are determined according to this characteristic. As a result, the media presents a behavior such as cheating in which women and men have an equal role and which is considered as negative in the context of social norms, to its readers in a manner that is completely biased against women.

\section{Kaynakça / References}

Alagözlü, N. (2009). Dil ve cins: Türkçe atasözlerinde ve deyimlerde kadın üzerine eğretilemeler ve toplum-bilişsel yapı. International Journal of Central Asian Studies, 13, 37-48.

Alankuş, S. (1998). Medyada kadın/beden temsil (siyaset)i: http://www.politikadergisi.com/sites/default/files/kutuphane/medyada_kadin_beden_temsil_siyaseti.pdf Erişim Tarihi: 05.02.2019

Cangöz, İ. (1999). Kitle iletişim kurumlarında etki sorunsalı ve bir izleyici araştırması. Yayınlanmamış Doktora Tezi, Anadolu Üniversitesi İletişim Bilimleri Enstitüsü, Eskişehir. 
Çelenk, S. (2010). Kadınların medyada temsili ve etik sorunlar, televizyon haberciliğinde etik (Ed. Bülent Çaplı ve Hakan Tuncel), Ankara: AU ILEF, 229-236.

Dursun, Ç. (2004). Haber hakikat ve iktidar ilişkisi. Ankara: Elips Kitap.

Durur, E. (2011). İnşacı yaklaşım içinde çerçeveleme kuramı ve haberin çerçevelenişi. Atatürk İletişim Dergisi, 2, 21-32.

Düzgit, S. (2011). Avrupa Birliği-Türkiye ilişkilerine post yapısalcı yaklaşım: Almanya örneğinde dış politika ve söylem analizi. Uluslararası İlişkiler Dergisi, 8(29), 49-70.

Karaduman, S. (2017). Eleştirel söylem çözümlemesinin eleştirel haber araştırmalarına katkısı ve sunduğu perspektif. Maltepe Üniversitesi İletişim Fakültesi Dergisi, 4(2), 31-46.

Okan, Z. (1998). Dil ve cinsiyet: Reklam dili çözümlemesi. Çukurova Üniversitesi Sosyal Bilimler Enstitüsü Dergisi, 5(5), 187-198.

Özarslan, H ve Güran, M. (2015). İletişim araştırmalarında çerçeveleme paradigması: Son döneme ait bir inceleme. Selçuk Illetişim Dergisi, 8 (4), 32-48.

Scheufele, D. A. veTewksbury, D. (2007). Framing, agenda setting, and priming: the evolution of three media effects models. Journal of Communication, 57(1), 9-20.

Solak, Ö. (2011). Küçük ağa romanının eleştirel söylem analizi. Akademik Bakış Dergisi, Türk Dünyası Araştırmaları Vakfı, 26, 1-14.

Uluç, Hıncal, Bu nasıl Magazin (köşe yazısı): https://www.sabah.com.tr/yazarlar/uluc/2017/12/23/bu-nasil-magazin Erişim tarihi: 05.02.2019

\section{Kaynakça Bilgisi / Citation Information}

Özkan, Ö. (2019). Medyadaki etik sorunlardan biri olarak cinsiyet ayrımcllığ1 magazin basınından örnek haber incelemesi. OPUS-Uluslararası Toplum Araştırmaları Dergisi, 10(17), 877-903. DOI: 10.26466/opus.524006 